\title{
CS-ASA: a new computational tool for advanced analysis of steel frames
}

\section{CS-ASA: uma nova ferramenta computacional, para análise avançada de estruturas de aço}

Andréa Regina Dias da Silva

D.Sc., Professor,

Graduate Program in Civil Engineering (PROPEC),

Department of Civil Engineering/

School of Mines, UFOP, Ouro Preto, MG, Brazil

andreadiassilva@yahoo.com.br

Ícaro Machado Prado

M.Sc., Graduate Program in Civil Engineering (PROPEC), Department of Civil Engineering/ School of Mines, UFOP, Ouro Preto, MG, Brazil icaroprado@gmail.com

\section{Ricardo Azoubel da Mota Silveira}

D.Sc., Professor,

Graduate Program in Civil Engineering (PROPEC) Department of Civil Engineering/School of Mines, UFOP, Ouro Preto, MG, Brazil

ricardo@em.ufop.br

\section{Resumo}

Esse trabalho apresenta uma nova ferramenta computacional, para análise avançada estática e dinâmica de estruturas de aço reticuladas planas, desenvolvida com base no Método dos Elementos Finitos. Duas fontes de não linearidades são consideradas nas análises: a geométrica, que considera os efeitos da deslocabilidade da estrutura; e a física, causada, principalmente, pelas características mecânicas dos materiais utilizados na construção civil. Imperfeições relacionadas com o carregamento, geometria do sistema e tensões residuais podem, também, serem consideradas. Para se ilustrarem alguns dos recursos e análises que diferenciam essa ferramenta dos programas comerciais existentes, a estabilidade estática e dinâmica de alguns sistemas estruturais, com ligações rígidas e semirrígidas, é avaliada. As respostas obtidas por outros pesquisadores são usadas, para validar as formulações e as metodologias de solução não linear, implementadas nessa ferramenta, e para atestar a eficiência desse programa caseiro de análise estrutural.

Palavras-chave: Análise avançada, análise não linear estática, análise não linear dinâmica, não linearidade geométrica, não linearidade física, ligação semirrígida, estrutura de aço.

\section{Abstract}

A new computational tool for advanced static and dynamic analyses of steel framed structures based on the Finite Element Method has been developed and is presented herein. Two sources of nonlinearity can be considered in these analyses, i.e.: the geometric, which considers the nonlinear effects of structure displacements; and the physical, which considers the nonlinear effects of the mechanical characteristics of the material used in civil construction. Loading, geometric and residual stress imperfections can also be considered. To illustrate some of the features and capabilities that differentiate this tool from existing commercial programs, static and dynamic stability analyses of some structural systems with rigid and semi-rigid connections are evaluated. The results obtained by other researchers are used to validate the nonlinear formulations and numerical solution methodologies implemented in CS-ASA, and to attest the efficiency of the structural analysis program presented herein.

Keywords: Advanced analysis, nonlinear static analysis, nonlinear dynamic analysis, geometric nonlinearity, material nonlinearity, semi-rigid connections, steel frame. 


\section{Introduction}

With the development of the civil, naval, oceanic and aeronautical industries, the appearance of more resistant material, and creation of new constructive techniques, the nonlinear behavior of the systems begins to be relevant in diverse problems of structural mechanics, and should be considered in the analyses. In addition, engineering interest in designing lighter and more slender structures is growing and the final structural system product is becoming more competitive. Moreover, these lighter and more slender structures usually cannot be analyzed and designed without their dynamic effects also being considered. The unknown levels and characteristics of the dynamic response can lead to system failure during the cyclic loading application, due to the accumulation of structural damages. Related studies have been developed with the objective of examining steel structure nonlinear behavior, i.e.: Barsan and Chiorean (1999), Maleck (2001), Sekulovic and Nefovska (2004; 2008), Zubydan
(2010), Aristizabal-Ochoa (2011), Yang et al. (2011), Thai and Kim (2011), and Vimonsatit et al. (2012).

Therefore, with the changes in structural conceptions and the requirements for more needed verification of structural behavior, there is an increasing search for computational systems with resources for nonlinear static and dynamic analyses. According to Surovek-Maleck et al. (2004) and, more recently, Wong (2009), although the computational tools that consider physical and geometrical nonlinear models, as well as geometric and residual stress imperfections, evolve quickly, the available commercial programs with all of these features are still a rarity. This may be due to the complexity of the analysis and the unfamiliarity of meaning and importance of these nonlinear effects in structural behavior. In this context, a new computational system for advanced structural analysis, CS-ASA, is presented in this article. The main characteristic of the program is the accomplishment of the nonlinear static and dynamic analyses of steel members and plane framed structures. In these analyses, the geometric nonlinearity, or second-order effects (P- $\Delta$ and $\mathrm{P}-\delta)$, can be simulated; as well as those introduced by considering semi-rigid connections, and steel inelasticity. The influence of initial geometric imperfections (out of plumbness and out of straightness) and residual stresses can also be considered. The introduction of all these nonlinear effects into the numerical models and formulations defines a Structural Advanced Analysis. This methodology for the analysis and design of steel structures makes it possible to establish the stability and ultimate strength of the structural members or system in a direct manner, without the necessity of separate verification of each member's capacity (Chen and Toma, 1994). Structural systems with known numerical or analytical solutions are herein analyzed to validate the nonlinear formulations adopted and to demonstrate the applicability of the computational system.

\section{The CS-ASA computational system}

Developed in Fortran 95/2003 language (Metcalf et al., 2004) and based on the Finite Element Method (FEM), CS-ASA performs the nonlinear static and dynamic analyses of steel members and framed system structures. The three steps of the numerical simulation process (preprocessing, analysis and post-processing) are illustrated in Figure 1. Pre-processing consists in the numerical model definition (data file input). The data related with the model is then processed to obtain the structural results (nodal forces, nodal displacements, among others) that will be printed in text files (post-processing). These files are exemplified in Figure 2. The nonlinear effects simulated are also shown in Figure 1.

Recently, Prado (2012) developed an interactive graphics preprocessing tool, named CS-ASA Preprocessor, whose primary purpose is to assist the analyst in using the CS-ASA. Besides the structural modeling (finite element mesh, boundary conditions, applied loading, semi-rigid joints, among others), information regarding the type of analysis as well as the solution strategy can be generated by the preprocessor developed. As a result of structural modeling and analysis definition, data files are produced, here called neutral files, which can be used by CS-ASA users as input information. All

\section{CS - ASA}

Computational System for Advanced Structural Analysis

Steel Framed Structures

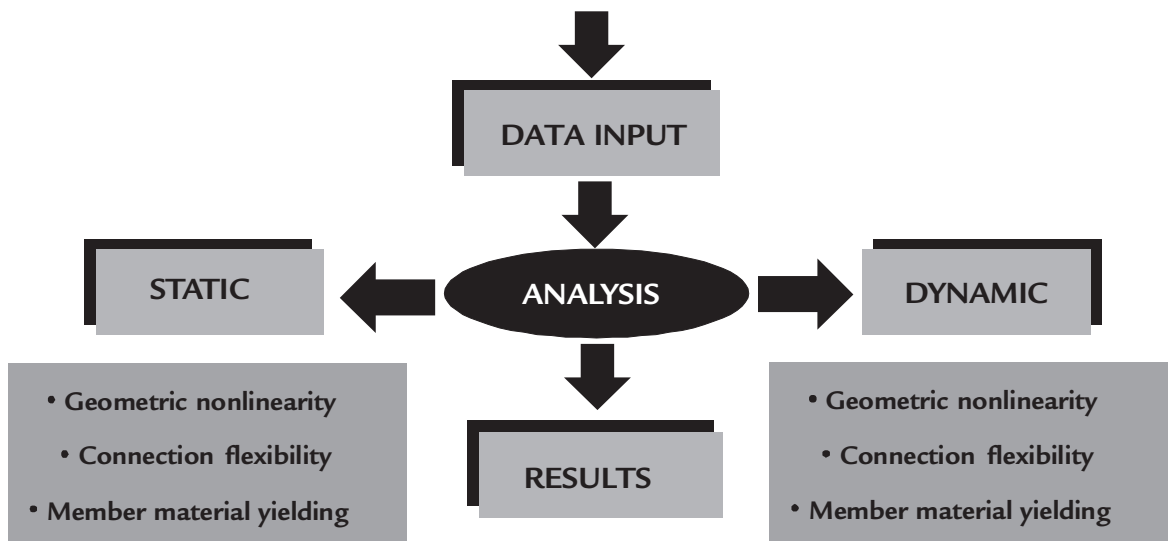

Figure 1

CS-ASA program: analysis and nonlinear effects considered (Silva, 2009). 
the necessary information to perform a structural modeling will be recorded in the FILEIN1.d file shown in Figure 2, via CSASA Preprocessor (Figure 3A). The data to perform a nonlinear static analysis, or even a vibration analysis of a pre-loaded structure, is recorded in the FILEIN2.d file, and Figure 3B shows that the dialogues present in CS-ASA Preprocessor can help the analyst in the generation of this second data file. The FILEIN3.d input file is necessary when a transient

Figure 2

Data input and results exit (Silva, 2009). dynamic analysis is performed. Besides the nonlinear FE formulation, other related data in this file are: time step number, time increment and iterative process tolerance. The nodal displacement, velocity and acceleration initial conditions, the viscous damping and the dynamic excitation function shall also be indicated. As in the two previous files, this third input file can also be generated using the CS-ASA Preprocessor (Figure 3C).

This interactive graphical environ- ment was developed using the $\mathrm{C}$ programming language (Rangel Netto et al., 2004). The IUP interface system and the CD two dimensional graphics library resources are also used for computational environment creation (see: http://www.tecgraf.puc-rio. br/iup and http://www.tecgraf.puc-rio. $\mathrm{br} / \mathrm{cd})$.

Looking to provide different analysis options for structural system modeling, several beam-column element formulations were adopted. The formulations

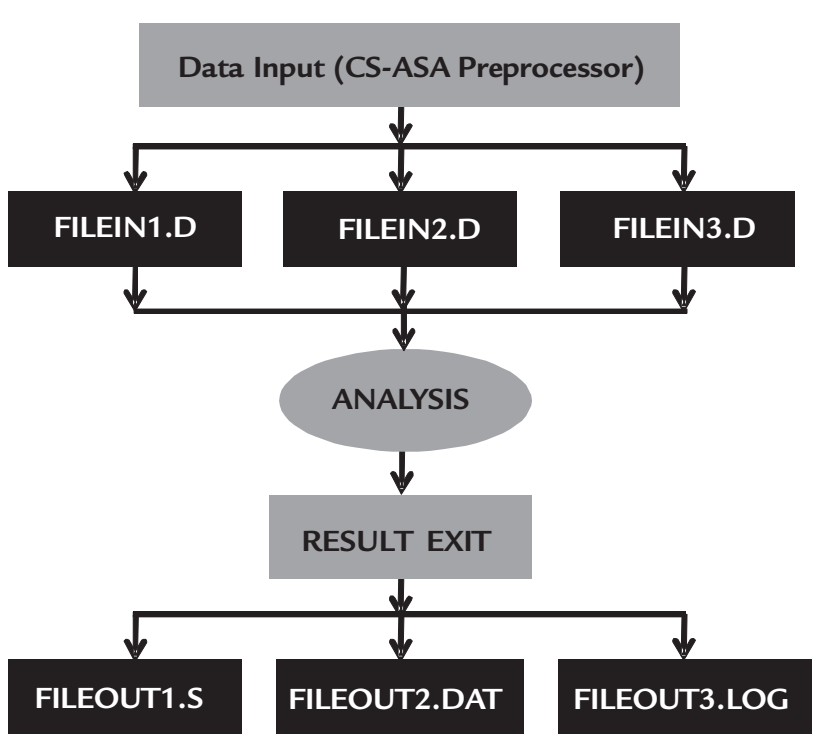

Figure 3

CS-ASA Preprocessor (Prado, 2012).

(A) FILEIN1.d tool box General information.

(B) FILEIN2.d tool box Nonlinear static analysis.

(C) FILEIN3.d tool box -

Dynamic analysis

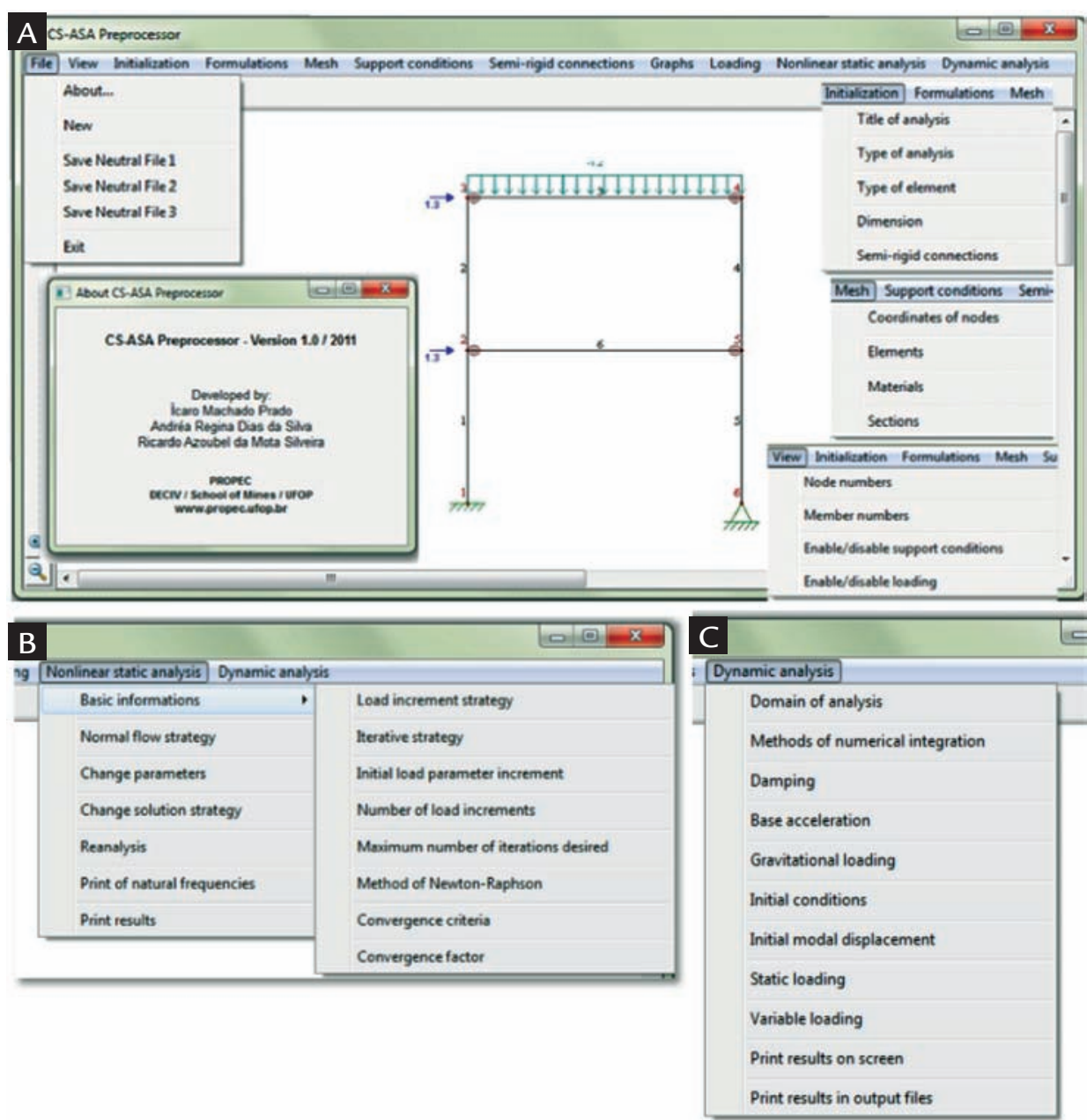


implemented in CS-ASA for second-order, connection flexibility and inelasticity effects simulations (referenced in Figure 1) are shown in Table 1. Such formulations are based on original publications indicated in Table 1. The SOF formulations (second-order formulations) consider the effects of geometric nonlinearities. These effects appear due to geometrical modification of the structure during the body deformation process. Large displacements and rotations, but small deformations are supposed. The formulations SOF-1 and SOF-2 are based on the Bernoulli-Euler's theory of beams and follow the updated Lagrangian approach. The SOF-3 formulation is derived from Timoshenko's theory, enabling second-order analysis of thick structures, and the total Lagrangian reference is used.

Unlike the criteria currently adopted in structural design, the joints between members do not behave the same as in idealized conditions: perfectly rigid or ideally pinned. The connections used in current practice present semi-rigid behavior that can substantially influence the structural system's stability and force distribution. Here, the semi-rigid connection is modeled as a spring element linking the structural members. The connection elements are physically attached to the ends of the beam-column element, maintaining the equilibrium and compatibility conditions, and the joint degrees of freedom are embedded in the beam-column stiffness tangent relationship. The spring's presence introduces relative rotations in nodes of that element's ends by modifying the equations that describe the nonlinear behavior of the structural system. Three different procedures are used to modify such equations that consider the effects of the connection's flexibility when programming the SRF formulations (semi-rigid formulations).

The steel inelasticity process changes the internal force distribution in the profile cross section and in all of the structure. Here, the study of the frame inelastic behavior is performed through PHF formulations (plastic-hinge formulations), which follow the basis of the refined plastic-hinge method. This method monitors the process of cross section early yielding until its total plastification, and residual tensions can also be considered. The plasticity effects associated with the formation of plastic-hinge are captured by a strength-reducing dimensionless parameter. This parameter changes with the level of loading by tracking the plastic region progress on the element ends and follow the specification recommendations.

\begin{tabular}{c|c|c|c}
\hline Nonlinear effects & \multicolumn{3}{|c}{ Finite element formulations } \\
\hline $\begin{array}{c}\text { Geometric } \\
\text { nonlinearity }\end{array}$ & $\begin{array}{c}\text { SOF-1 } \\
\text { (Alves, 1995) }\end{array}$ & $\begin{array}{c}\text { SOF-2 } \\
\text { (Yang and Kuo, 1994) }\end{array}$ & $\begin{array}{c}\text { SOF-3 } \\
\text { (Pacoste and Eriksson, 1997) }\end{array}$ \\
\hline $\begin{array}{c}\text { Connection } \\
\text { flexibility }\end{array}$ & $\begin{array}{c}\text { SRF-1 } \\
\text { (Chan and Chui, 2000) }\end{array}$ & $\begin{array}{c}\text { SRF-2 } \\
\text { (Chen and Lui, 1991) }\end{array}$ & $\begin{array}{c}\text { SRF-3 } \\
\text { (Sekulovic and Salatic, 2001) }\end{array}$ \\
\hline Material yielding & PHF-1 (Liew, 1992) & \multicolumn{2}{|c}{ PHF-2 (Chan and Chui, 2000) } \\
\hline Combined effects & AAF-1 (Liew, 1992) & \multicolumn{2}{c}{ AAF-2 (Chan and Chui, 2000) } \\
\hline
\end{tabular}

In PHF-1 formulation, this parameter is defined by the plastic strength surface provided by AISC (2003) or NBR8800 (2008). In the PHF-2 formulation, which follows the BS5950 (1990) standard requirements, this parameter is evaluated from the internal forces and geometrical characteristics of the section. Finally, the AAF formulations (advanced analysis formulations), which were obtained by modifying the PHF formulations, consider the influence of the connection flexibility in the structure's second-order inelastic analysis. Details on all these formulations and about the nonlinear solution methodologies adopted in static and dynamic analyses are in Silva (2009).

The CS-ASA still does not have an integrated graphical post-processor for a quick visualization of structural response. The generated program results are then stored in files of different extensions for subsequent treatment. These files are exemplified in Figure 2. The equilibrium paths, resultant internal forces diagrams, degree of member section plasticization, modes and frequencies of vibration, connection and section hysteretic behavior, displacements, velocities and accelerations time histories, resonance curves, and element internal forces are some of the results generated by the program.

Table 1

Formulations implemented in CS-ASA.

\section{Some modeling using the CS-ASA}

This section shows some applications made with the CS-ASA program. Initially, Figure 4A illustrates the static analysis carried out with a classic structural system known as Lee Frame (Schweizerhof and Wriggers, 1986). By its sensitivity to second-order effects, this slender frame is commonly used to validate the nonlinear solution strategies and the geometric nonlinear finite element formulations. The equilibrium paths, with load and displacement limit points, were obtained by controlling the horizontal and vertical displacements $(u$ and $v$ ) of the point of load application. The complete curves were achieved using an efficient load increment and iterative strategies coupled to the Newton-Raphson method. Nonlinear iterative strategies as arch-length technique, minimum residual displacement norm, generalized displacement control, among others, are implemented in CS-ASA, and are also described in Silva (2009).

The influence of static preloading on dynamic stability of a sinoidal arch is shown in Figure 4B. The geometric and connection nonlinearities are considered in this study. Nonlinear relationship be- tween the distributed load $P$ and the arch's lowest natural vibration frequency was verified for different support conditions represented by the $S$ parameter, which is defined as a function of arch bending stiffness EI. The increase in support flexibility, decreasing the structural system's stiffness, changes significantly the dynamic characteristics.

Figures $4 \mathrm{C}$ and $4 \mathrm{D}$ show the nonlinear static and dynamic analyses results of a two-story frame with semi-rigid beam-column connections. The nonlinear behavior of these joints is simulated 

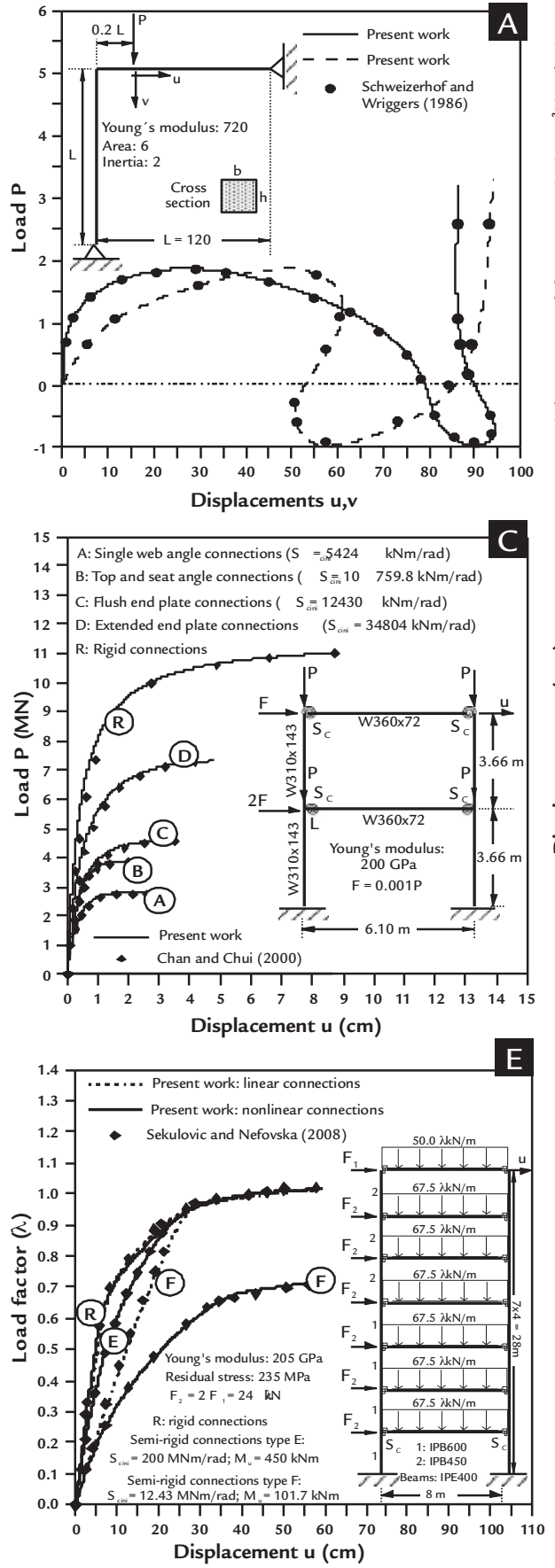

capacity and stability of the structure. The load-top displacement curves show that the limit loads are smaller for more flexible joints. In dynamic analysis, the frame with beam-column connections of the type $C$ is subjected to cyclic loading, and the history of the structure's top horizontal displacement is presented in Figure 4D. It can be notice that initially the displacement oscillates with variable amplitudes characterizing the transient regime and after approximately $6 \mathrm{~s}$, enters into permanent regime, which is perceived by the constant movement ranging around $\pm 5 \mathrm{~cm}$. During the period of constant response, the energy introduced into the structure by external load excitation and the dissipated energy by the semi-rigid joints is approximately
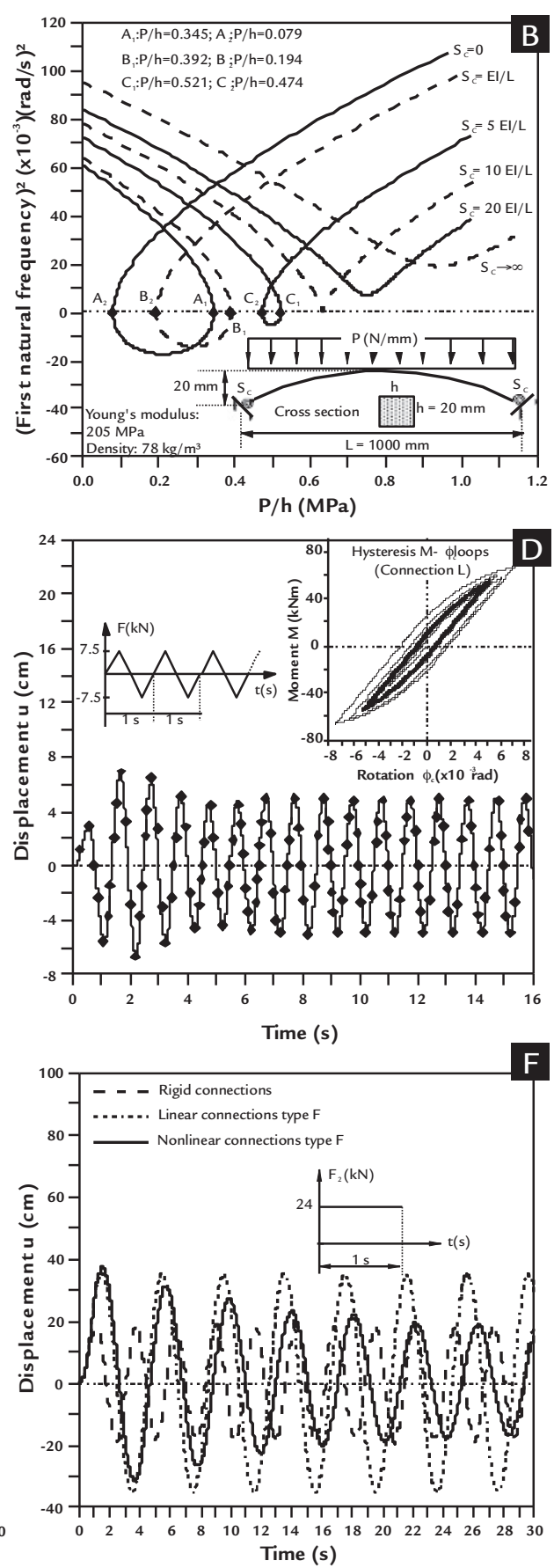

equal. This can be verified by looking at the hysteretic cycle of joint $L$ in Figure 4D.

Figures $4 \mathrm{E}$ and $4 \mathrm{~F}$ are respectively related to static analysis where the effect of steel inelasticity is considered, and to dynamic analysis performed with a sevenstory frame with rigid and semi-rigid joints of the types $E$ and $F$. In Figure 4E, noticeable is that the limit load factor increases with connection flexibility reduction. For the frame with rigid connections, the influence of the beams and columns plastic moment capacity in the structural behavior is evident. For the frame with semi-rigid connection type $F$ with nonlinear moment-rotation behavior, it is apparent that the connection flexibility has considerable influence on the overall analysis, considering the material to have elastic behavior, investigated the loading 
structural system behavior, since the connection failure moment $(101.7 \mathrm{kNm})$ is significantly less than the beams' plastic moment $(307 \mathrm{kNm})$. Figure $4 \mathrm{~F}$ shows the influence of hysteretic damping promoted by semi-rigid connections on the frame amplitudes. No viscous damping was considered in this analysis.

Figure 5A shows the dynamic behavior of a simple steel frame subjected to a harmonic base excitation of amplitude of $3.81 \mathrm{~m} / \mathrm{s}^{2}$ and vibration frequency equal to $15.7 \mathrm{~m} / \mathrm{s}^{2}$. The possibility of consideration of this kind of excitation, which reflects the variation of soil acceleration over time, is extremely important because it allows simulating the earthquake effects.

Recently, a routine for simulating nonlinear cyclic material behavior was implemented in the CS-ASA system. So, the time-history nonlinear inelastic response of a planar steel frame is shown in Figure 5B. One can observe a perma- nent plastic deformation response when considering material non-linearity (refined plastic-hinge approach). It also shows the hysteretic path of moment-plastic versus deformation at support $A$, where it can be observed that there is energy dissipation throughout the plastic-hinges, which must be taken into account because it is essential in assessing structural energy absorption capacity when subjected to seismic excitations.

With the flexibility increase of modern structures, the geometric nonlinear effects can cause the appearance of undesirable vibrations. In this case, the relationship between vibration frequency and the amplitude of the response, the resonance curve, provides important information regarding vibration analysis, as it indicates the type, hardening or softening, and degree of non-linearity of the structural system. Figures 5C-D illustrates these analyses for the L-Frame. Figure 5C shows
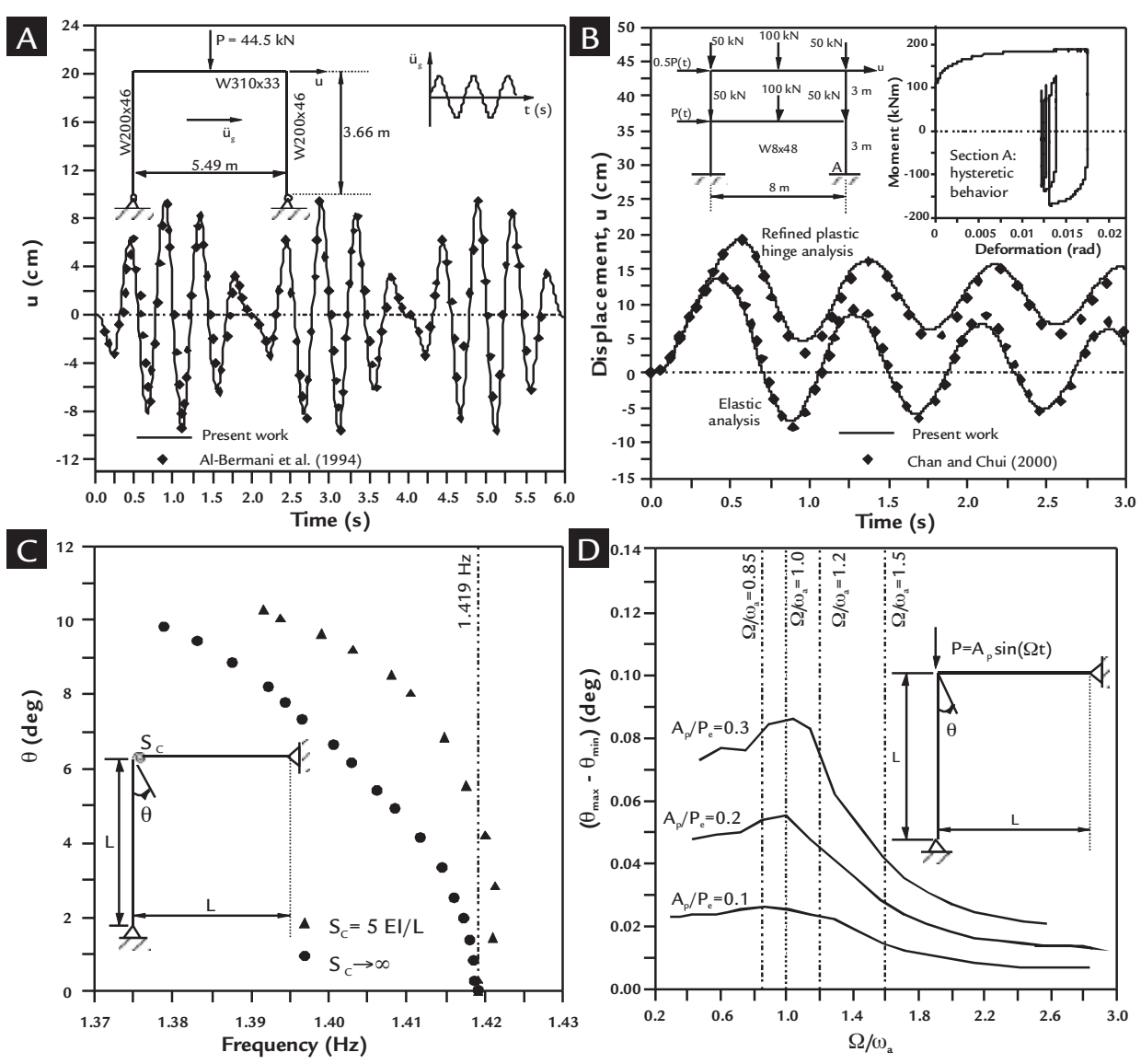

\section{Final remarks}

A computational program developed for nonlinear static and dynamic analyses of steel framed structures has been presented. The numerical results obtained with this software demonstrate the validity of formulations implemented in CS-ASA. Accuracy and efficiency in nonlinear behavior assessment of the steel structures were also verified.

The possibility of considering different nonlinear effects in the numerical models and formulations enables the CS-ASA system for advanced structural analysis. It is noteworthy that while the frequency-amplitude relationship for different values of $S_{c}$ (stiffness connection) up to very large deflections. The frame shows a hardening behavior, producing an increase of the nonlinear frequency with the vibration amplitude. For a harmonic load (Figure 5D), the resonance curves for the L-frame are obtained considering a perfectly rigid connection between the beam and the column for increasing values of the excitation amplitude, $A_{p}$. This figure exhibits the variation of the amplitude of the steady state solution $\left|\theta_{\max } \theta_{\min }\right|$ with the frequency ratio $\mathrm{W} / \mathrm{w}_{\mathrm{a}}$, where $\mathrm{W}$ is the excitation frequency of the harmonic load and $\mathrm{w}_{a}$ is the first natural frequency of the damped frame. The influence of the nonlinearity is small, which is explained by the frequency-amplitude relation shown in Figure 5C. However, as $A_{p}$ increases, the resonance peak moves to a higher frequency range due to the hardening character of the nonlinearity.
Figure 5

CS-ASA structural applications (Part 2).

(A) Portal frame: dynamic inelastic analysis.

(B) Shallow arch: free vibration analysis.

(C) L-frame: nonlinear

frequency-amplitude relation.

(D) L-frame: resonance curves. many commercial software packages currently provide some good methods for performing second-order analysis, few have a robust inelastic analysis capability, including codes and specification requirements, to be used in static and dynamic nonlinear analysis applications. 
Therefore, the computational system presented here is a homemade developed nonlinear finite element tool with a very simple data-structure, and can be considered to be a powerful dedicated computational system for advanced analysis of steel structures.

The graphical tool developed, the CS-ASA Preprocessor, with its friendly

\section{Acknowledgments}

The authors express their gratitude to CAPES, CNPq and FAPEMIG for the interface, assisted the authors in the structural models editing/visualization, and made the numerical studies more efficient. CS-ASA continues to expand, and a new feature is the possibility of solving bilateral contact problems between the structural system and its members (frames, arches, columns and beams) and an elastic foundation (Ma- ciel, 2012); also recently, a new iterative strategy for nonlinear static analysis, based on normal flow technique, was developed and implemented in CS-ASA (Maximiniano, 2012). It should be mentioned that a graphical post-processor for the CS-ASA is now being tested and the next publication should bring details of this new computational tool. financial support received in the development of this research. Special thanks go to Harriet Reis for her editorial reviews.

\section{References}

AISC. Manual of steel construction, load and resistance factor design specification for structural steel buildings. Chicago, IL: American Institute of Steel Construction, AISC, 2003.

AL-BERMANI, F.G.A., LI, B., ZHU, K., KITIPORNCHAI, S. Cyclic and seismic response of flexibly jointed frames. Engineering Structures, v. 16, n. 4, p. 249-255, 1994.

ALVES, R.V. Instabilidade não-linear elástica de estruturas reticuladas espaciais. Rio de Janeiro: PEC - COPPE/UFRJ, 1995, 257 f. (Tese de Doutorado).

ARISTIZABAL-OCHOA, I.D. Stability and non-linear second-order elastic analysis of beam and framed structures with semi-rigid connection using the cross method. Engineering Structures, v. 32, n. 10, p. 3258-3268, 2011.

BARSAN, G.M., CHIOREAN, C.G. Computer program for large deflection elastoplastic analysis of semi-rigid steel frameworks. Computers \& Structures, v. 72, n. 6, p. 669-711, 1999.

BS5950: Structural use of steelwork in buildings. Part 1. London, England: British Standards Institution, 1990.

CHAN, S.L., CHUI, P.P.T. Nonlinear static and cyclic analysis of steel frames with semi-rigid connections. Kidlington, UK: Elsevier, 2000.

CHEN, W.F., LUI, E.M. Stability design of steel frames. Boca Raton, Flórida: CRC Press, 1991.

CHEN, W.F., TOMA, S. Advanced analysis of steel frames. Boca Raton, Florida: CRC Press, 1994.

LIEW, J.Y.R. Advanced analysis for frame design. West Lafayette: Purdue University, 1992. 392 f. (Ph.D. Dissertation).

MACIEL, F.V. Equilíbrio e estabilidade de elementos estruturais com restrições bilaterais impostas por bases elásticas. Ouro Preto: Programa de Pós-graduação em Engenharia Civil, DECIV/Escola de Minas/UFOP, 2012. 107 f. (Dissertação de Mestrado).

MALECK, A.E. Second-order inelastic and modified elastic analysis and design evaluation of planar steel frames. Atlanta, GA: School of Civil and Environmental Engineering, Georgia Institute of Technology, 2001. 578 f. (Ph.D. Dissertation).

MAXIMIANO, D.P. Uma técnica eficiente para estabilizar a estratégia do resíduo ortogonal na análise não linear de estruturas. Ouro Preto: Programa de Pósgraduação em Engenharia Civil, DECIV/Escola de Minas/UFOP, 2012. 67 f. (Dissertação de Mestrado).

METCALF, M., REID, J., COHEN, M. Fortran 95/2003 Explained. (3rd. ed.). Oxford University Press, USA, 2004.

NBR 8800. Projeto de estruturas de aço e de estruturas mistas de aço e concreto de Edifícios. Rio de Janeiro, Brasil: Associação Brasileira de Normas Técnicas, 2008.

PACOSTE, C., ERIKSSON, A. Beam elements in instability problems. Computer Methods in Applied Mechanics and Engineering, 144, p. 163-197, 1997.

PRADO, I.M. CS-ASA Preprocessor: programa gráfico interativo de préprocessamento para análise avançada de estruturas. Ouro Preto: Programa de Pós-graduação em Engenharia Civil, DECIV/Escola de Minas/UFOP, 2012. 144 f. (Dissertação de Mestrado). 
RANGEL NETTO, J.L.M., CERQUEIRA, R.F.G., CELES FILHO, W. Introdução a estrutura de dados: com técnicas de programação em C. Rio de Janeiro: Editora Campus, 2004. $250 \mathrm{f}$.

SCHWEIZERHOF, K.H., WRIGGERS, P. Consistent linearization for path following methods in nonlinear FE analysis. Computer Methods in Applied Mechanics and Engineering, 59, p. 269-279, 1986.

SEKULOVIC, M., NEFOVSKA, M. Contribution to transient analysis of inelastic steel frames with semi-rigid connections. Engineering Structures, 30, p. 976-989, 2008.

SEKULOVIC, M., NEFOVSKA, M. Static inelastic analysis of steel frames with flexible connections. Journal of Theoretical and Applied Mechanics, v. 31, n.2, p.101-134, 2004.

SEKULOVIC, M., SALATIC, R. Nonlinear analysis of frames with flexible connections. Computers \& Structures, v. 79, n. 11, p. 1097-1107, 2001.

SILVA, A.R.D. Sistema computacional para a análise avançada estática e dinâmica de estruturas metálicas, Ouro Preto: Programa de Pós-graduação em Engenharia Civil, DECIV/Escola de Minas/UFOP, 2009. 322 f. (Tese de Doutorado).

SUROVEK-MALEK, A., WHITE, D.W., LEON, R.T. Direct analysis for design of partially restrained steel framing system. Journal of Structural Engineering, v.131, n. 9, p. 1376-1389, 2004.

THAI, H-T., KIM, S-E. Practical advanced analysis software for nonlinear inelastic dynamic analysis of steel structures. Journal of Constructional Steel Research, v.67, n. 3, p. 453-161, 2011.

VIMONSATIT, V., TANGARANVONG, S., TIN-LOI, F. Second-order elastoplastic analysis of semirigid steel frames under cyclic loading. Engineering Structures, v.4, n. 5, p. 127-136, 2012.

WONG, M.B. Plastic analysis and design of steel structures. Elsevier, 2009. $246 \mathrm{f}$.

YANG, Y.B., KUO, S.B. Theory \& analysis of nonlinear framed structures. Prentice Hall, 1994. $450 \mathrm{f}$.

YANG, Y.B., CHEN, C.T., LIN, T.J., HUNG, C.R. Consistent virtual work approach for the nonlinear and postbuckling analysis of steel frames under thermal and mechanical loadings. Engineering Structures, v. 3, n. 6, p. 1870-1882, 2011.

ZIEMIAN, R.D. Advanced methods of inelastic analysis in the limit states design of steel structures, Ithaca, NY: School of Civil and Environmental Engineering, Cornell University, 1990. 265 f. (Ph.D. Dissertation).

ZUBYDAN, A.H. A simplified model for inelastic second order analysis of planar frames. Engineering Structures, v. 32, n. 10, p. 3258-3268, 2010.

Artigo recebido em 08 de abril de 2012. Aprovado em 16 de abril de 2013. 